By DONALD CONEY

\title{
Libraries and the Long Haul
}

$A$ message from the President of the Association of College and Reference Libraries.

$I^{\mathrm{T}}$

T DOES NOT TAKE much wit or imagina-

tion to see behind today's headlines the call for a long and determined effort to turn defense into victory, but it takes an acute awareness of reality to convert this common knowledge into action. Librarians of scholarly libraries, like their colleagues of the faculty, are often accused of lying snug in their ivory towers, but I doubt if there is any group in the country more fully aware of the dangers and demands of the present crisis than college and university faculties. In this awareness, librarians should not lag behind.

Institutions of higher learning are confronted by a wartime dilemma, and the problems common to dilemma-solving must be shared by their libraries as the paramount service agencies of the scholar and the learner. On the one hand, scholarly libraries must assume their appropriate share of immediate and direct contribution to the war effort in services and in personnel; on the other, there is the necessity, of utmost importance, to maintain normal functions in the service of present training and research so that the postwar era may not be barren of hope. The first problem is today's, and the second is tomorrow's. Tomorrow cannot be robbed for the present, but today's work must be done. Librarians must not collapse supinely in the face of this dilemma. They must attack it positively and hold the scales in even balance between emergency requirements and certain demands of the future.

Immediately confronting us is the problem of throwing our libraries into gear with the special wartime activities of the institutions with which we are associated. The supply of materials for defense training courses no longer presents new problems to us, but we are now confronted with the need to act as information centers on civilian defense, on student guidance with reference to enlistment in the armed forces, on the supply of materials dealing with the causes and future of the war, and presently, when the country has got its second wind, on the problems of the postwar period-that time which is the only excuse for the present crisis. These problems and others that will spring into being with each new pressure of events are "must" activities. They must be dealt with swiftly, efficiently, with imagination and with skill.

Concurrently, although we cannot do business as usual, we must carry on much of our usual business in preparation for the greater emergencies after the war. The essential education of the rising generation must not suffer if the war is to be worth fighting. If we want to live in a world of individual freedom, tomorrow's men and women must be educated to an appreciation of its value. If the lamp of knowl-

(Continued on page II6) 
they choose to teach with library materials rather than student-bought textbooks will progress be made in teaching with books. Moreover, only insofar as they use the collections for research and public service can those collections become useful in the solution of baffling educational, social, economic, and political problems.

In conclusion, may I personally and on behalf of the board of library trustees and the staff of the Joint University $\mathrm{Li}$ braries express our deep appreciation to those who have helped with their moral and financial support to make the Joint University Library a reality. You have enabled us to take the first important step to provide an adequate library and with your further assistance and encouragement we hope we may take the other essential steps.

\section{Librarians and the War}

(Continued from page Ioo)

enabling the decisions of the American people to be based on the intellect rather than on the emotions. We don't want to repeat the mistakes of the last world war and the peace which followed it.

Let us then as a united group devote our attention for the duration to the education and enlightenment of the American people, first for victory and then for world-wide understanding with no thought of destruction or revenge.

Let us all work for victory and perma-

\section{Libraries and the Long Haul}

\section{(Continued from page IOI)}

edge is not to flicker and burn $\operatorname{dim}$ for decades, institutions of higher learning and their libraries must be prepared to carry on activities of basic research by continuing to an appropriate degree their normal functions.

Problems of both kinds must be met by libraries under conditions of peculiar diffculty. Library personnel is diminishing by induction into the armed services, by attraction to defense work, and through the current reduction and future extinction of N.Y.A. and W.P.A., and, more seriously, by the lowering of income. The avail-

ability of essential library supplies is becoming increasingly less. Humble examples are the increasing costs and ultimate shortage of catalog card stock and shortages in the essential materials for binding. Important publications for research published in foreign countries are generally unavailable in this country for many reasons. Only by hard work and ingenuity can we meet the current and pressing demands and at the same time keep our houses in order for the future. It will be a long haul but we are going to make it! 